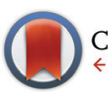

CrossMark \&lick for updates

Cite this: Org. Biomol. Chem., 2017, 15, 1164

\section{On the nature of the electronic effect of multiple hydroxyl groups in the 6-membered ring - the effects are additive but steric hindrance plays a role too $\uparrow$}

\author{
Christian Marcus Pedersen* and Mikael Bols*
}

Research during the last two decades has shown a remarkable directional component of the substituent effects of hydroxy groups, which has a profound effect on the properties of hydroxylated compounds such as carbohydrates. While the epimerisation of a single hydroxyl function is well studied the consequence of multiple epimerisations is more speculative. In this work the effect of three epimerisations was investigated. To this end epimeric 2-phenyl iminoxylitols that have a phenyl group as a conformational anchor and thus hydroxyl groups in the axial or equatorial position, respectively, were synthesized and their $\mathrm{p} K_{\mathrm{a}}$ and conformation were studied. The results show that the large difference in the electronic effect between the axial and equatorial hydroxyls is partially cancelled by counteracting steric hindrance from 1,3-diaxial interactions. Hydrogen bonding does not appear to play any role in the electronic influence of the hydroxyl groups.
Received 7th November 2016 Accepted 23rd December 2016 DOI: $10.1039 / \mathrm{c} 6 \mathrm{ob} 02427 \mathrm{k}$ rsc.li/obc tuent contribution of the axial or equatorial substituent. The difference in $\mathrm{p} K_{\mathrm{a}}$ values can be attributed to several effects, but charge-dipole interactions are in common for all and provide a satisfactory explanation for the observations: each $\mathrm{C}-\mathrm{O}$ bond constitutes a dipole while each ammonium group has a positive charge (mainly dispersed on the surrounding atoms) - the closer the negative ends of the dipoles are to the positive charge the more favourable the structure. With this in mind it is not surprising that the stereoelectronic effect is coupled with a conformational effect, which is dependent on the protonation stage of the ring nitrogen, i.e. upon protonation it becomes even more favourable to have electro-negative substituents axially oriented as they effectively are less electron withdrawing than when equatorial due to the charge-dipole interaction. The fact that these stereoelectronic effects are strong enough to introduce conformational changes has been observed in a number of cases ${ }^{5}$ e.g. the hexahydropyridazine derivative (Fig. 1), which shifts conformation from 1 to 2 depending on $\mathrm{pH}^{6}$ and also in bicyclic sulfonium salts like $\mathbf{3}$, which resides in an all axial conformation, which suffers from sterically unfavourable 1,3-diaxial interactions. ${ }^{7}$ Generally, as the $\mathrm{C}-\mathrm{X}$ dipole increase, with $\mathrm{C}-\mathrm{F}$ as the extreme, ${ }^{8}$ the conformational change placing the dipole in an axial orientation becomes increasingly important for the stabilization of the piperidinium ion. ${ }^{9}$ In many cases the difference in stability between the two conformations is small and mixtures of conformations are present. The ratio of such mixtures influences the overall $\mathrm{p} K_{\mathrm{a}}$ value and can be determined directly by NMR
Department of Chemistry, University of Copenhagen, Universitetsparken 5, 2100

Copenhagen Ø, Denmark.E-mail: cmp@chem.ku.dk, bols@chem.ku.dk

$\dagger$ Electronic supplementary information (ESI) available. See DOI: 10.1039/ c6ob02427k 

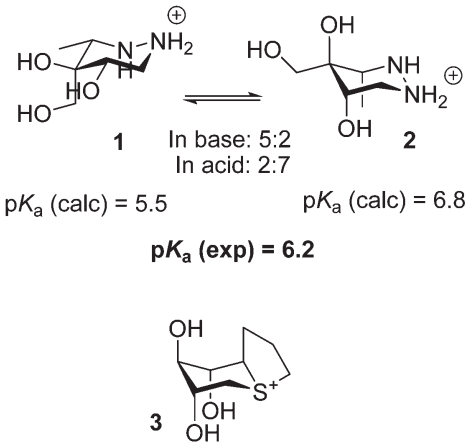

Fig. 1 At the top the calculated $\mathrm{p} K_{\mathrm{a}}$ values of two conformational extremes of an azasugar (top) and the measured value. Below an all axial bicyclic sulfonium salt illustrating the preference of axial hydroxyl groups in rings with positively charged heteroatoms.

from the intermediate $J$-couplings measured at room temperature $^{10}$ or even from the $\mathrm{p} K_{\mathrm{a}}$ itself. $^{6}$ The $\mathrm{p} K_{\mathrm{a}}$ values for the two conformational extremes 1 and 2 (Fig. 1) can be calculated using the formula mentioned above giving $\mathrm{p} K_{\mathrm{a}}=5.5$ and 6.8, respectively, whereas the measured value is 6.2 as a result of both conformers being present. The connection between the substituent effects in nitrogen heterocycles, mainly piperidines, and other heterocycles has been thoroughly studied over the last decade, ${ }^{11}$ and it is well accepted that the stereoelectronic effects observed in piperidines are linearly correlated with the anomeric reactivity in e.g. carbohydrates. ${ }^{3 b, 12}$ As an example it has been revealed that there are linear correlations between the rate in glycoside hydrolysis or glycosylation reactions and the acidity of piperidinium salts, with analogous substituent patterns. ${ }^{12 a}$ The generality of these effects is such that they with great success have been used to predict the behaviour and reactivity of carbohydrates such as anhydrosugars $^{13}$ and axial rich glycosyl donors ${ }^{14}$ as well as hydroxymethyl conformers. ${ }^{15}$

The $\mathrm{p} K_{\mathrm{a}}$-calculations of piperidinium derivatives assume that substituent effects are additive, which for a significant number of reference compounds hold true with a relatively small margin of error. However extreme differences in the basicity of conformers are predicted by this method and such differences have so far not been confirmed experimentally due to the unavailability of appropriate reference compounds. The purpose of this work was to investigate whether such extreme differences in base strength would be observed in diastereoisomers. For this purpose we targeted the two epimers of 5-Cphenyliminoxylitol, 6 and 7, and determined their $\mathrm{p} K_{\mathrm{a}}$ values (Fig. 2). As model compounds 6 and 7 are ideally suited because the very bulky phenyl group in the 5-position (carbohydrate numbering) acts as a conformational anchor fixing the conformation so that the three hydroxyl groups will either be all equatorial or all axial, i.e. giving the two extremes. The differences in $\mathrm{p} K_{\mathrm{a}}$ values are therefore large and calculated to be $2.0 \mathrm{p} K_{\mathrm{a}}$ units, with 7 being the most basic amine (Fig. 2).

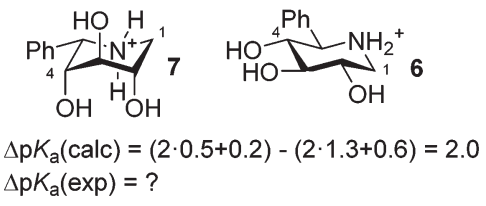

Fig. 2 The two target model compounds and the calculation of the difference between their $\mathrm{p} K_{\mathrm{a}}$ values.

\section{Results and discussion}

The two target piperidines have either a D-gluco or L-ido stereochemistry if numbered from the $\mathrm{CH}_{2}$ group using carbohydrate numbering. In view of this, diacetone glucose is an obvious starting material as the stereogenic centers at C2, C3 and C4 can be maintained unchanged while phenyl and nitrogen are installed at C5. Using this approach aldehyde 8 was prepared in 3 steps from glucose acetonide ${ }^{16}$ and a Grignard addition using phenyl magnesium bromide was carried out to give an approx. 12:1 ratio of the epimers (9 and 13), with L-ido (13) being the major product. ${ }^{17}$ Since both were required, a twostep conversion of $\mathbf{1 3}$ involving PDC oxidation and $\mathrm{NaBH}_{4}$ reduction provided the $\mathrm{D}$-gluco derivative $\mathbf{9}$ as the main product (approx. 10:1 over 13). The L-ido isomer 13 was readily tosylated followed by nucleophilic substitution using $\mathrm{NaN}_{3}$ in DMF to give the fully protected azide 14. Removal of the isopropylidene group and hydrogenation and benzyl hydrogenolysis over $\mathrm{Pd} / \mathrm{C}$ afforded the 5-C-phenyl-D-gluco-1,5-iminopentitol 6. The same approach could however not be applied for the epimeric alcohol 9 as the tosylation did not proceed even under more forcing conditions. This is probably due to steric hindrance. To circumvent this, the 3-O-benzyl group was removed by hydrogenolysis and a cyclic sulfite $\mathbf{1 1}$ was prepared using thionyl chloride. Treating this with $\mathrm{NaN}_{3}$ in DMF gave the desired azide 12. The acidic removal of the isopropylidene protective group followed by hydrogenolysis using $\mathrm{Pd} / \mathrm{C}$ and triethylsilane (TESH) gave the target compound L-2-phenyl-iminoxylitol 7. The hydrogenation/hydrogenolysis reactions were generally sluggish and attempts to use more forcing conditions mainly gave the pyridine derivative 15. Changing the catalyst to Pearlman's catalyst $\left(\mathrm{Pd}(\mathrm{OH})_{2}\right)$ or Raney® Ni did not improve the reaction.

In order to study the influence of internal hydrogen bonding four additional derivatives were synthesized. The $\mathrm{H}$-bond donating capability of the $3-\mathrm{OH}$ group was investigated by preparing the 3-O-methyl derivatives 18 and 20 (Scheme 2). The D-gluco epimer 18 was synthesized by 3-O-methylation of diacetone glucose followed by selective removal of the 5,6-Oisopropylidene group, periodate cleavage and addition of phenylmagnesium bromide to obtain alcohol 16 predominantly as the L-ido isomer. Tosylation and subsequent $\mathrm{S}_{\mathrm{N}} 2$ substitution using sodium azide gave azide 17, which was treated with $\mathrm{AcOH}(75 \%)$ to successfully remove the isopropylidene group from where hydrogenolysis to $\mathbf{1 8}$ was attempted. Neither hydrogenolysis with $\mathrm{H}_{2}(\mathrm{~g})$ in the presence of Pd/C, Pearlman's 


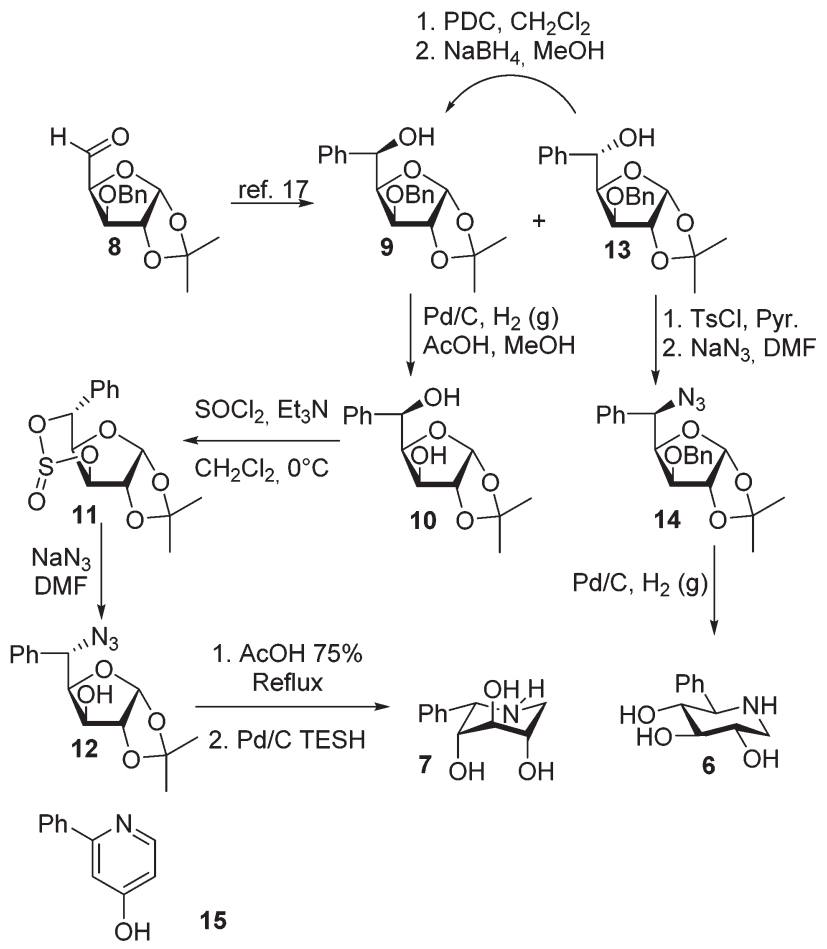

Scheme 1 Synthesis of the two model compounds 6 and 7. Pyridine 15 is a dominant side product in the final reductive amination.

catalyst $\left(\mathrm{Pd}(\mathrm{OH})_{2}\right)$ or RANEY® $\mathrm{Ni}$ gave satisfactory results nor did a two-step procedure of the Staudinger $\left(\mathrm{Ph}_{3} \mathrm{P}\right)$ reaction and $\mathrm{NaBH}_{4}$ reduction give satisfactory yield. However, changing the hydrogen source in the catalytic reduction solved the problem and hence using triethylsilane (TESH) in combination with $\mathrm{Pd} / \mathrm{C}$ gave the 3-O-methyl 2-phenyl-L-iminoxylitol 18 in reproducible good yields. In order to prepare 20 it was necessary to start with the late intermediate $\mathbf{1 2}$ (Scheme 1) where the azide was already present. Compound $\mathbf{1 2}$ was methylated with MeI/ $\mathrm{NaH}$, deprotected with acetic acid and subjected to reductive amination according to the protocol above (Pd/C, TESH) to give 20 (Scheme 2).

The D-gluco epimer 23 and the L-ido epimer 27 (Scheme 3) having 2- and 4-hydroxyls protected with methyl groups were prepared starting from the late stage intermediates 14 and 12 (Scheme 1). Compound $\mathbf{1 2}$ had to be benzylated to the 3-O benzyl derivative $\mathbf{2 4}$ (Scheme 3). Then both epimers followed the same reaction sequence of removal of isopropylidene with acetic acid followed by reductive amination, which could be performed using $\mathrm{Pd} / \mathrm{C}$ and TESH without any loss of benzyl ether. The obtained piperidines 21 and $\mathbf{2 5}$ were Boc-protected, methylated and the benzyl groups removed using Pearlman's catalyst and hydrogen. The treatment of the obtained piperidines 22 and 26 with TFA gave the desired compounds 23 and 27 as their corresponding piperidinium trifluoroacetates (Scheme 3).

\section{Conformational studies}

With the 6 compounds $(\mathbf{6}, 7, \mathbf{1 8}, \mathbf{2 0}, 23$ and 27) prepared, their respective conformations were studied using NMR. Since the

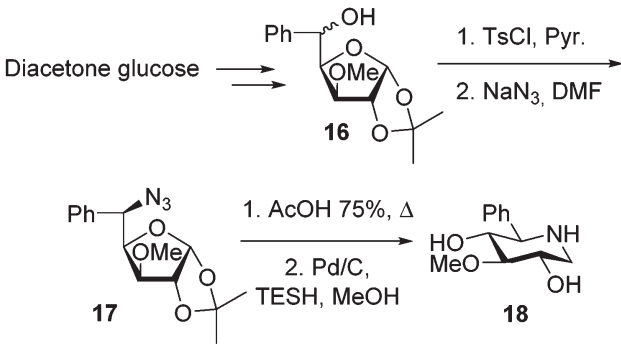

Only one isomer isolated

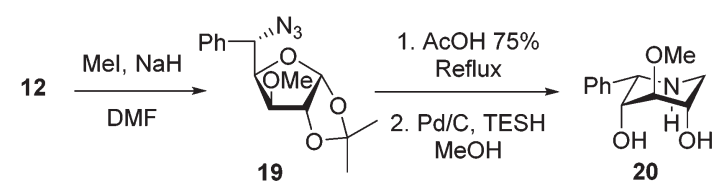

Scheme 2 Synthesis of the 3-O-methylated derivatives.

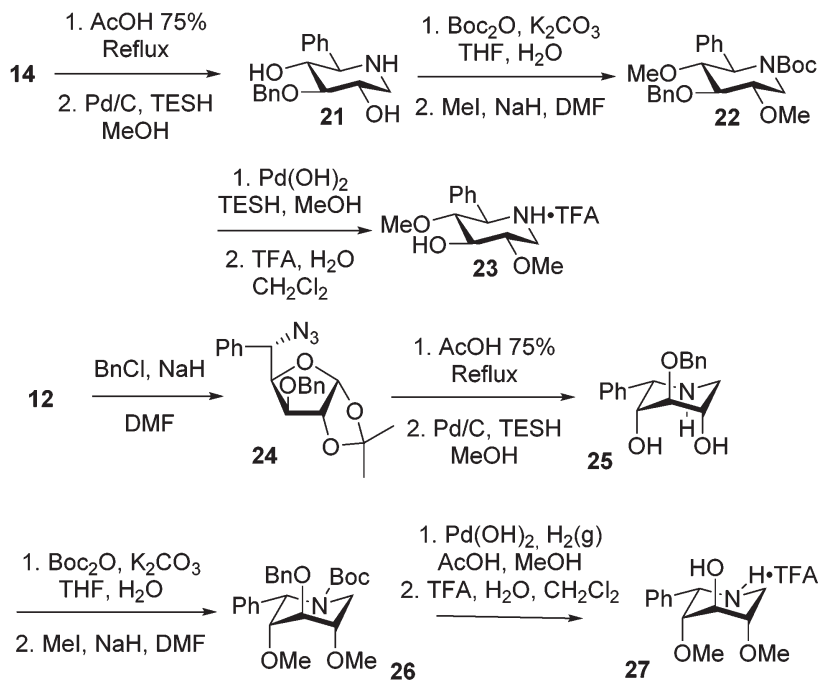

Scheme 3 Synthesis of the two 2,4-di-O-methylated derivatives.

conformation can be strongly dependent on the $\mathrm{pH}$, as mentioned in the Introduction, the compounds were studied in both their amine and ammonium forms by adding either NaOD or DCl to the NMR sample. As Table 1 shows there is practically no conformational change upon protonation and hence the role of the 2-phenyl group as a conformational anchor that keeps the conformation fixed in one chair form is confirmed. In the D-gluco series $(\mathbf{6}, \mathbf{1 8}$ and 23$)$ the compounds, regardless of $\mathrm{pH}$, show large trans vicinal couplings in the range 9-12 $\mathrm{Hz}$ for $J_{23}, J_{34}$ and $J_{45}$ showing that these compounds are in the ${ }^{4} C_{1}$ chair conformation (Table 1). The compounds in the L-ido series $(7,20$ and 27$)$ display very small couplings (broad singlets - bs) for $J_{23}, J_{34}$ and $J_{45}$, which is consistent with a ${ }^{1} C_{4}$ chair conformation (Table 1) and inconsistent with a ${ }^{4} C_{1}$ chair or $B_{1,4}$ boat conformation. In both cases this is as anticipated. 
Table $1{ }^{1} \mathrm{H}$-NMR chemical shifts and couplings of piperidines $6-27$

\begin{tabular}{|c|c|c|c|c|c|}
\hline Cmp. & $\delta \mathrm{H}-1 \mathrm{ab}\left(J_{1 \mathrm{a} 1 \mathrm{~b}}\right)$ & $\delta \mathrm{H}-2\left(J_{1 \mathrm{ab} 2}\right)$ & $\delta \mathrm{H}-3\left(J_{23}\right)$ & $\delta \mathrm{H}-4\left(J_{34}\right)$ & $\delta \mathrm{H}-5\left(J_{45}\right)$ \\
\hline $6(\mathrm{D}+)$ & $3.07(12.4)$ & $3.90(11.6,0)$ & $3.58(9.3)$ & $3.93(9.3)$ & $4.15(10.8)$ \\
\hline 23 & $2.41,2.47(12.5)$ & $3.4(\mathrm{bm})$ & $3.56(\sim 8.5)$ & $3.34(9.1)$ & $3.53(9.3)$ \\
\hline $23(\mathrm{D}+)$ & $3.82,3.08(12.5)$ & $3.73(5.2,11.2)$ & $3.79(9.2)$ & $3.83(9.2)$ & $4.27(10.3)$ \\
\hline 7 & $3.19,3.07(14.5)$ & 3.77 (bs) & 4.06 (bs) & 3.87 (bs) & $4.20(\mathrm{bs})$ \\
\hline $20(\mathrm{D}+)$ & $3.59,3.53(13.7)$ & $4.30(\mathrm{bs})$ & $3.79(<3)$ & $4.25(<3)$ & $4.62(\mathrm{bs})$ \\
\hline 27 & $3.09,3.04(14.4)$ & $3.33(\mathrm{~m}, 3.6)$ & $4.22(\mathrm{bs})$ & $3.46(\mathrm{~m})$ & $4.22(\mathrm{bs})$ \\
\hline $27(\mathrm{D}+)$ & $3.16,3.20(\mathrm{~m})$ & $4.26(\mathrm{~m})$ & 3.41 (bs) & $3.53(\mathrm{~s})$ & 4.32 \\
\hline
\end{tabular}

$\mathrm{m}$ is multiplet, $\mathrm{s}$ is singlet and bs is broad singlet.

\section{Titrations}

The $\mathrm{p} K_{\mathrm{a}}$ values of the 6 compounds $(6,7,18,20,23$ and 27) were determined using potentiometric titration. At least two titrations were conducted per compound and the average results are presented in Table 2 with the uncertainty being within 0.1 units. From the results we see some general and interesting trends. Firstly, the difference in the $\mathrm{p} K_{\mathrm{a}}$ value between the epimeric pairs, $6 / 7,18 / 20$ or $23 / 27$, is 1.1 to $1.3 \mathrm{pH}$ units, respectively, with the all axial epimer being more basic. While this qualitatively is the anticipated result it is considerably less than is predicted from calculations as these predict a difference of approximately $2 \mathrm{p} K_{\mathrm{a}}$ units. Secondly $O$-methylation of the $3-\mathrm{OH}$ has no significant influence on the $\mathrm{p} K_{\mathrm{a}}$ value as seen from the essential identical values obtained from the pairs $\mathbf{6 / 1 8}$ and $7 / 20$. Thirdly the 2,4-di-O-methyl derivatives are found consistently less basic than the hydroxylated counterpart as seen from the 0.4 unit lower $\mathrm{p} K_{\mathrm{a}}$ value

Table 2 Structures and $\mathrm{p} K_{\mathrm{a}}$ values of phenyl piperidines

23 Compound

compared to 6 and the 0.6 unit lower $\mathrm{p} K_{\mathrm{a}}$ value of 27 compared to 7 .

\section{Discussion}

The $\mathrm{p} K_{\mathrm{a}}$ values of the phenylpiperidines in the ${ }^{4} C_{1}$ conformation $(6,18$ and 23) are 6.1, 6.1 and 5.7 and are very much in line with the values found in similar compounds or are at least readily explained. A comparison of the $\mathrm{p} K_{\mathrm{a}}$ value of 6.1 for compound 6 with that of 1-deoxynojirimycin (28) of 6.7 (Fig. 3$)^{3 a}$ reveals that the value is reasonable since the only difference between these molecules is that the hydroxymethyl group in $\mathbf{2 8}$ has been replaced with a phenyl group. This should decrease the basicity since the phenyl group is considerably more electron withdrawing as reflected by its higher inductive substituent constant (0.94 versus 0.66$),{ }^{18}$ and this is seen as the $\alpha$-phenyl group reduces the base strength by $1.3^{19}$ whereas hydroxymethyl only reduces it by $0.7 .^{3 a}$ The influence on the $\mathrm{p} K_{\mathrm{a}}$ of $O$-methylation in compounds 18 and 23 is also in line with what was previously found with 1-deoxynojirimycin derivatives where the tetra-O-methyl derivative $\mathbf{2 9}^{11 b}$
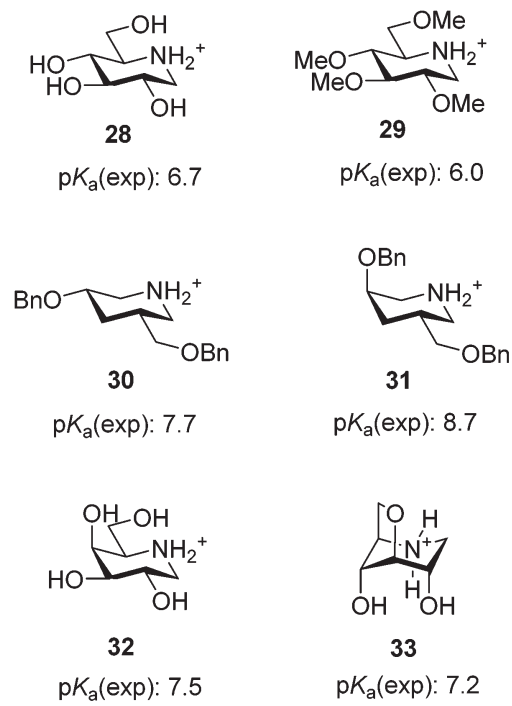

33

$\mathrm{p} K_{\mathrm{a}}(\exp ): 7.2$

Fig. 3 Experimental $p K_{a}$ values from the literature. 
(Fig. 3) was less basic ( $\mathrm{p} K_{\mathrm{a}}$ 6.0) than 28 ( $\mathrm{p} K_{\mathrm{a}}$ 6.7). The reason for this reduced basicity is the slightly higher electron withdrawing power of $\mathrm{O}$-alkyl over $\mathrm{OH}$, i.e. when $4-\mathrm{OH}$ groups are replaced with $\mathrm{OMe} \mathrm{p} K_{\mathrm{a}}$ drops to 0.7 . However a single methylation on the most remote hydroxyl group has little influence as 18 that has the same $\mathrm{p} K_{\mathrm{a}}$ as $\mathbf{6}$. But a larger base reducing effect of 0.4 is seen when the closer 2 - and $4-\mathrm{OH}$-groups are methylated (23). Altogether this shows that 6, 18 and 23 behave as we would expect from earlier findings: the $\mathrm{p} K_{\mathrm{a}}$ is mainly a result of the inductive and electrostatic effects of the phenyl group and the 3 equatorial $\mathrm{OH}$ or $\mathrm{OMe}$ groups, with $\mathrm{OMe}$ being slightly more electron withdrawing compared to an $\mathrm{OH}$ group.

However the $\mathrm{p} K_{\mathrm{a}}$ values of the phenylpiperidines in the ${ }^{1} C_{4}$ conformation (7, 20 and 27) are significantly smaller than would be anticipated from earlier findings. If we as above set the base reducing influence of the $\alpha$-phenyl group to $1.3,{ }^{19}$ we find that the $\mathrm{p} K_{\mathrm{a}}$ of 7 should be $8.2\left(\mathrm{p} K_{\mathrm{a}}=\right.$ 10.7-1.3-0.5-0.5-0.2) if only inductive and electrostatic effects played a role and not the observed 7.4 (Table 2). The fact that the basicity is remarkably lower is also seen from many literature examples some of which are shown in Fig. 3. Epimerisation of a single benzyloxy group from the equatorial to axial position in piperidines $\mathbf{3 0}$ and $\mathbf{3 1}$ increases the $\mathrm{p} K_{\mathrm{a}}$ by $1.0,{ }^{11 b}$ which is almost the same as the difference between the pairs 23 and 27 despite the fact that there are two methoxy groups and one hydroxyl group changing from equatorial to axial. Also galactodeoxynojirimycin 32 (Fig. 3) has a $\mathrm{p} K_{\mathrm{a}}$ of 7.5 and is thus slightly more basic than 7 despite the fact that it has only 1 and not 3 axial $\mathrm{OH}$ groups. Thus the all axial derivatives 7, 20 and 27 are clearly much less basic than anticipated from previous data except for one example: the 3,6-anhydro derivative 33 (Fig. 3 ) was previously prepared and its $\mathrm{p} K_{\mathrm{a}}$ value was determined to be $7.2,{ }^{11 b}$ which is also an extraordinary low value. This extraordinary, according to electronic effects, low basicity that compounds 7, 20, 27 and 33 display must be due to the second important factor that influences the base strength of amines - steric hindrance. ${ }^{2 a}$ These compounds differ from the other piperidines in that they all have two axial non-hydrogen substituents $\beta$ to the nitrogen. Therefore the protonation of the nitrogen will lead to two 1,3-diaxial steric interactions between a hydrogen and a hydroxyl or methoxy group, which obviously is unfavourable enough to reduce the $\mathrm{p} K_{\mathrm{a}}$ of these compounds with 0.8 to 1.0 units (Fig. 4). The fact that the influence of the 1,3-diaxial interactions from hydrogen is high is clearly seen in literature examples: while tert-butylcyclohexane (34) is well known to have the large tert-butyl group, equatorial cis-5-tert-butyl-2-methyl-1,3-dioxane (35) has the tert-butyl group predominantly at the axial position simply due to the lack of 1,3-diaxial interactions with hydrogen (Fig. 4). ${ }^{20}$ The effect is seen directly on the $\mathrm{p} K_{\mathrm{a}}$ in base pairs 36/37 and 38/39 (Fig. 4). ${ }^{21}$ The compounds having the ethylene bridge $\beta$ to the amine (37 and 39 ) are 0.87 and 0.75 , respectively, less basic than their analogues having the ethylene bridge $\alpha$ (36 and 38). As the electronic effects from the carbon substituents are negligible ${ }^{2 a}$ the lower base strength must be due to the steric hindrance caused by the 1,3-diaxial interaction between

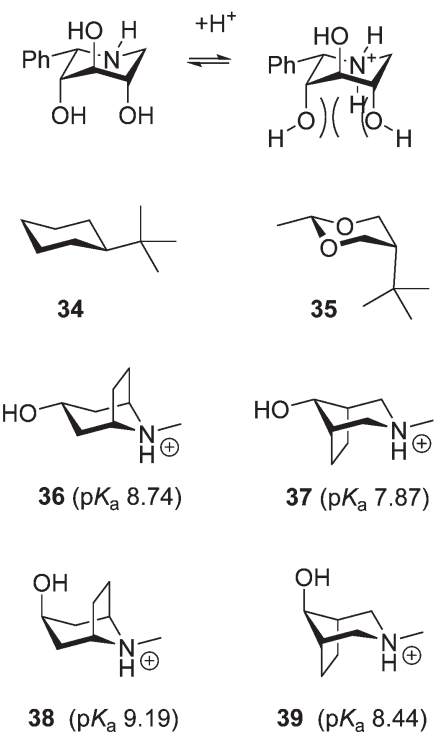

Fig. 4 Steric interactions upon protonation of 7 and the preferred conformations of tert-butyl derivatives which show the profound effect of 1,3-diaxial steric interactions with hydrogen. The steric hindrance versus protonation of the amine is the $\mathrm{p} K_{\mathrm{a}}$ of the base pairs $36 / 37$ and $38 / 39$.

the $\beta$-bridge and ammonium hydrogen. Therefore 7, 20 and 27 do not become as basic as one would expect based on electronic effects because they are more difficult to protonate due to hindrance. The base lowering effect from the steric hindrance of the two axial hydroxyl groups is about 0.8 , which is very similar to the $\mathrm{p} K_{\mathrm{a}}$ difference in base pairs $36 / 37$ and $38 / 39$. This similarity is reasonable as the methylenes in $\mathbf{3 7}$ and 39 should be comparable in size to $\mathrm{OH}$ and less bulky than methyl.

\section{Conclusions}

This work has shown that an all-axial 2,3,4-trihydroxypiperidine has a significantly lower base strength than can be accounted for by the electronic effect. The corresponding all equatorial trihydroxypiperidine, on the other hand, has the $\mathrm{p} K_{\mathrm{a}}$ one would expect based on the electronic effect. The reason for the low $\mathrm{p} K_{\mathrm{a}}$ of the axial isomer is the two unfavourable 1,3-diaxial interactions that is present when the amine is protonated, which makes it more difficult to protonate. Thus the electronic effects are additive but $\mathrm{p} K_{\mathrm{a}}$ is reduced by the counteracting steric effect. Partial $O$-methylation has no significant effect other than reducing the base strength slightly due to the somewhat higher electron-withdrawing effect of OMe compared to $\mathrm{OH}$.

\section{Experimental}

\section{5-Azido-5-deoxy-1,2-O-isopropylidene-5-C-phenyl- $\alpha$-L-ido-} pentofuranose (12)

Diol 10 (1.66 g) was dissolved in $\mathrm{CH}_{2} \mathrm{Cl}_{2}(50 \mathrm{~mL})$ together with $\mathrm{Et}_{3} \mathrm{~N}(3.24 \mathrm{~mL}, 23.3 \mathrm{mmol}, 4$ eq. $)$ and $\mathrm{SOCl}_{2}(840 \mu \mathrm{L}$, 
$11.6 \mathrm{mmol}, 2$ eq.) was added slowly. The reaction was followed by TLC (ethyl acetate: petroleum ether $1: 4$, product $R_{\mathrm{f}}=0.5$ ) and quenched with water upon completion. The water phase was extracted with $\mathrm{CH}_{2} \mathrm{Cl}_{2}$ and the combined organic phases were washed with $\mathrm{NH}_{3} \mathrm{Cl}$ (aq.) and brine, followed by drying $\left(\mathrm{MgSO}_{4}\right)$ and concentration in vacuo. Flash chromatography yielded 11 (1.77 g, 91\%), which was a ratio of 45 : 55 stereoisomers at sulphur. $\left[{ }^{1} \mathrm{H} \mathrm{NMR}\left(500 \mathrm{MHz}, \mathrm{CDCl}_{3}\right): \delta\right.$ 7.49-7.35 (m, 5H, Ar), 6.15 (d, $J=3.6 \mathrm{~Hz}, 1 \mathrm{H}, \mathrm{H} 1), 6.10$ (d, $J=3.7 \mathrm{~Hz}, 1 \mathrm{H}$, $\mathrm{H} 1^{\prime}$ ), 5.52 (d, $\left.J=7.4 \mathrm{~Hz}, 1 \mathrm{H}, \mathrm{H} 5\right), 5.16$ (d, $\left.J=3.7 \mathrm{~Hz}, 1 \mathrm{H}, \mathrm{H} 3^{\prime}\right)$, 4.98 (d, $\left.J=7.2 \mathrm{~Hz}, 1 \mathrm{H}, \mathrm{H} 5^{\prime}\right), 4.81$ (2 d, $\left.J \sim 3.6 \mathrm{~Hz}, 2 \mathrm{H}, \mathrm{H} 2, \mathrm{H} 2^{\prime}\right)$, $4.74\left(\mathrm{dd}, J=7.3,3.8 \mathrm{~Hz}, 1 \mathrm{H}, \mathrm{H} 4^{\prime}\right), 4.70(\mathrm{dd}, J=7.5,3.8 \mathrm{~Hz}, 1 \mathrm{H}$, H4), 4.64 (d, $J=3.8 \mathrm{~Hz}, 1 \mathrm{H}, \mathrm{H} 3$ ), 1.46, 1.45, 1.35, 1.34 (4 s, 12 $\mathrm{H}, \mathrm{Me}) .{ }^{13} \mathrm{C} \mathrm{NMR}\left(126 \mathrm{MHz}, \mathrm{CDCl}_{3}\right): \delta$ 136.2, 136.1, 129.0, 129.0, 128.8, 128.8, 126.5, 126.3 (8 $\mathrm{Ar} \mathrm{C}), 113.1\left(\mathrm{CMe}_{2}\right), 113.1$ (C'Me ${ }^{\prime}$ ), 106.4 (C1), 106.0 (C1'), 83.3, 83.0, 83.0, 82.3 (4 C, C2, C2', C4, C4'), 78.7 (C3), 77.0 (C5'), 73.5 (C3'), 71.9 (C5), 27.1, 27.0, 26.5 (4 Me).]

The cyclic sulfite $11(1.76 \mathrm{~g}, 5.64 \mathrm{mmol})$ was dissolved in DMF (25 mL) and $\mathrm{NaN}_{3}(2.5 \mathrm{~g}, 0.038 \mathrm{mmol}, 6.8$ eq.) was added. The reaction mixture was heated to $105{ }^{\circ} \mathrm{C}$ and left overnight. TLC (ethyl acetate-petroleum ether 1:3) showed full conversion (product $R_{\mathrm{f}}=0.25$ ) and the reaction was allowed to cool to room temperature, whereafter it was diluted with water and extracted with ethyl acetate. The organic phases were collected, washed with water and brine followed by drying over $\mathrm{MgSO}_{4}$ and concentration in vacuo. Flash chromatography (ethyl acetate-petroleum ether $1: 3$ ) yielded azide 12 $(1.51 \mathrm{~g}, 92 \%)$.

${ }^{1} \mathrm{H}$ NMR (500 MHz, $\left.\mathrm{CDCl}_{3}\right) \delta$ 7.45-7.32 (m, 5H, Ar), 6.01 (d, $J=3.7 \mathrm{~Hz}, 1 \mathrm{H}, \mathrm{H} 1), 4.79$ (d, $J=8.8 \mathrm{~Hz}, 1 \mathrm{H}, \mathrm{H} 5), 4.44$ (d, $J=3.7$ $\mathrm{Hz}, 1 \mathrm{H}, \mathrm{H} 2$ ), 4.35 (dd, $J=8.7,2.7 \mathrm{~Hz}, 1 \mathrm{H}, \mathrm{H} 4), 3.77$ (bs, $1 \mathrm{H}$, H3), 2.21 (s, 1H, 3-OH), 1.50 (s, 3H, Me), 1.29 (s, 3H, Me).

${ }^{13} \mathrm{C}$ NMR (126 MHz, $\mathrm{CDCl}_{3}$ ): $\delta$ 135.9, 129.0, 129.0, 127.8 (4C, Ar), $112.1\left(\mathrm{CMe}_{2}\right), 105.1$ (C1), 85.1 (C2), 83.2 (C4), 74.7 (C3), 64.7 (C5), 26.8 (Me), 26.2 (Me).

HRMS calculated $\mathrm{C}_{14} \mathrm{H}_{17} \mathrm{~N}_{3} \mathrm{O}_{4} \mathrm{Na}=314.1117$ found: 314.1112.

\section{1,5-Dideoxy-1,5-imino-5-phenyl-L-ido-pentitol (7)}

Azide 12 (0.319 g, $1.10 \mathrm{mmol})$ was dissolved in $30 \mathrm{~mL}$ THF and $2 \mathrm{~mL} \mathrm{HCl}(2 \mathrm{M})$ and refluxed for $20 \mathrm{~min}$. The reaction mixture was neutralized, concentrated and purified by flash chromatography (EA : PE $1: 2$ to $1: 0 ; R_{\mathrm{f}}=0.5$ in EA) to give the desired hemiacetal intermediate $(230 \mathrm{mg} ; 84 \%)$. A portion of this (0.183 $\mathrm{g}, 0.73 \mathrm{mmol})$ was then dissolved in EA-MeOH $(1: 1$; $4 \mathrm{~mL}$ ) and $\mathrm{Pd} / \mathrm{C}(10 \% \mathrm{Pd}$ ca. $10 \mathrm{mg})$ was added under a nitrogen atmosphere, which was subsequently exchanged with a hydrogen atmosphere (1 atm). After $1 \mathrm{~h}$ at $\mathrm{rt}$ the reaction mixture was filtered, concentrated in vacuo and purified by flash chromatography $\left(\mathrm{CHCl}_{3}: \mathrm{EtOH}, 5: 1\right.$ to $1: 1+\mathrm{NH}_{3} ; R_{\mathrm{f}}=$ 0.3 in $\mathrm{CHCl}_{3}$ : EtOH $2: 1+1$ drop $\mathrm{NH}_{3}$ conc. sol.) to give the desired product 7 (136 $\mathrm{mg}, 90 \%)$.

${ }^{1} \mathrm{H}$ NMR $\left(500 \mathrm{MHz}, \mathrm{D}_{2} \mathrm{O}\right): \delta 7.56-7.45(\mathrm{~m}, 5 \mathrm{H}), 4.71(\mathrm{~s}, 1 \mathrm{H}$, $\mathrm{H} 2), 4.19$ (s, 1H, H4), 4.15 (m, 1H, H5), 4.11 (bs, 1H, H3),
3.77-3.63 (bd, $J=13.7 \mathrm{~Hz}, 1 \mathrm{H}, \mathrm{H} 6), 3.53$ (bd, $J=13.7 \mathrm{~Hz}, 1 \mathrm{H}$, H6').

${ }^{13} \mathrm{C}$ NMR (126 MHz, D $\left.\mathrm{D}_{2} \mathrm{O}\right): \delta 133.7(\mathrm{Ph}), 129.1$ (2C, Ph), 126.9 (Ph), 70.8 (C3), 67.3 (C4), 65.7 (C5), 58.4 (C2), 46.6 (C6).

HRMS calculated $\mathrm{C}_{11} \mathrm{H}_{15} \mathrm{NO}_{3}+\mathrm{H}^{+}=210.1125$ found: 210.1126 .

\section{5-Azido-3-O-benzyl-5-deoxy-1,2-O-isopropylidene-5- $C$-phenyl- $\alpha$-D-gluco-pentofuranose (14)}

Alcohol 13 (1.66 g, $4.66 \mathrm{mmol}$ ) was dissolved in pyridine (25 mL) and TsCl (2.0 g, $10.2 \mathrm{mmol}, 2.2$ eq.) was added. The reaction mixture was heated to $90{ }^{\circ} \mathrm{C}$ and left for $18 \mathrm{~h}$. TLC (ethyl acetate-petroleum ether $1: 3 ; R_{\mathrm{f}}=0.2$ ) showed full conversion and the reaction was cooled to room temperature followed by dilution with ethyl acetate washing with water and brine. After concentration the crude product was dissolved in DMF (25 mL) and $\mathrm{NaN}_{3}$ (5 eq.) was added. The reaction was stirred at $105{ }^{\circ} \mathrm{C}$ for $18 \mathrm{~h}$ whereafter TLC (ethyl acetatepetroleum ether $\left.1: 3 ; R_{\mathrm{f}}=0.45\right)$ showed full conversion. The reaction was cooled to room temperature, diluted with water and extracted with ethyl acetate. The combined organic phases were washed with water ( 5 times) and finally brine. After concentration the crude product was purified by flash chromatography (ethyl acetate-petroleum ether $5: 1$ to $3: 1$ ) to give the product (1.23 g; 69\% over 2 steps).

${ }^{1} \mathrm{H}$ NMR (500 MHz, $\left.\mathrm{CDCl}_{3}\right) \delta 7.48-7.30(\mathrm{~m}, 10 \mathrm{H}, \mathrm{Ar}), 5.87$ (d, $J=3.7 \mathrm{~Hz}, 1 \mathrm{H}, \mathrm{H} 1), 4.84$ (d, $J=10.0 \mathrm{~Hz}, 1 \mathrm{H}, \mathrm{H} 5), 4.76$ (d, $J=$ $11.4 \mathrm{~Hz}, 1 \mathrm{H}, \mathrm{PhCH}_{2}$ ), 4.68 (d, $J=11.4 \mathrm{~Hz}, 1 \mathrm{H}, \mathrm{PhCH}_{2}$ ), 4.64 (d, $J=3.7 \mathrm{~Hz}, 1 \mathrm{H}, \mathrm{H} 2), 4.33$ (dd, $J=10.0,3.1 \mathrm{~Hz}, 1 \mathrm{H}, \mathrm{H} 4), 4.14$ (d, $J=3.1 \mathrm{~Hz}, 1 \mathrm{H}, \mathrm{H} 3), 1.47$ (s, 3H, Me), 1.30 (s, 3H, Me).

${ }^{13} \mathrm{C}$ NMR $\left(126 \mathrm{MHz}, \mathrm{CDCl}_{3}\right) \delta 137.3,136.9,128.8,128.6$, 128.6, 128.1, 128.1, 127.8 (12C, $2 \mathrm{Ar}), 111.9\left(\mathrm{CMe}_{2}\right), 105.3$ (C1), 81.9 (C2), 81.6 (C3), 81.5 (C4), $72.4\left(\mathrm{PhCH}_{2}\right), 62.9$ (C5), 26.9 (Me), 26.3 (Me).

HRMS calculated $\mathrm{C}_{21} \mathrm{H}_{23} \mathrm{~N}_{3} \mathrm{O}_{4} \mathrm{Na}=404.1586$ found: 404.1580

\section{1,5-Dideoxy-1,5-imino-5-phenyl-D-gluco-pentitol (6)}

Azide $14(0.127 \mathrm{~g}, 0.33 \mathrm{mmol})$ was treated with TFA and water in THF $(5 \mathrm{~mL})$ until the TLC showed full conversion of the starting material (ethyl acetate-petroleum ether $1: 3 ; R_{\mathrm{f}}=$ 0.45). The solvents were removed in vacuo and the crude was dissolved in ethyl acetate-MeOH $(1: 1,5 \mathrm{~mL})$ and $\mathrm{Pd} / \mathrm{C}$ (ca. $25 \mathrm{mg}$ ) was added. The reaction was stirred under a hydrogen atmosphere (1 atm) O.N. TLC (EtOH : $\left.\mathrm{CHCl}_{3}\right)$ showed the formation of the product $\left(R_{\mathrm{f}}=0.2\right)$. Yield $=79 \mathrm{mg}(77 \%)$.

${ }^{1} \mathrm{H}$ NMR (500 MHz, D 20$) \delta 7.55-7.48(\mathrm{~m}, 5 \mathrm{H}, \mathrm{Ph}), 4.23(\mathrm{~d}$, $J=10.8 \mathrm{~Hz}, 1 \mathrm{H}, \mathrm{H} 1), 4.02$ (dd, $J=9.3,10.8 \mathrm{~Hz}, 1 \mathrm{H}, \mathrm{H} 2) ; 3.99$ (ddd, $J=5.1,9.3,11.6,1 \mathrm{H}, \mathrm{H} 4), 3.68$ (t, $J=9.3 \mathrm{~Hz} .1 \mathrm{H}, \mathrm{H} 3$ ), $3.58(\mathrm{dd}, J=5.1,12.4 \mathrm{~Hz}, 1 \mathrm{H}, \mathrm{H} 5), 3.15$ (dd, $J=11.6,12.4 \mathrm{~Hz}$, $\left.1 \mathrm{H}, \mathrm{H} 5^{\prime}\right)$.

${ }^{13} \mathrm{C}$ NMR (126 MHz, D $\left.2 \mathrm{O}\right) \delta 131.9(\mathrm{Ph}), 130.3(\mathrm{Ph}), 129.6$ (Ph), 128.3 (Ph), 76.3 (C3), 70.9 (C2), 67.0 (C4), 62.9 (C1), 46.5 (C6).

HRMS calculated $\mathrm{C}_{11} \mathrm{H}_{15} \mathrm{NO}_{3}+\mathrm{H}^{+}=210.1125$ found: 210.1136 . 
5-Azido-5-deoxy-1,2-O-isopropylidene-3-O-methyl-5- $\mathrm{C}$-phenyl$\alpha$-D-gluco-pentofuranose (17)

1,2-O-Isopropylidene-3-O-methyl- $\alpha$-D-glucofuranose $\quad(4.75 \mathrm{~g}$, $20.3 \mathrm{mmol})$ was dissolved in EtOH:water $(9: 1)$ and $\mathrm{NaIO}_{4}$ ( $6.5 \mathrm{~g}, 30.4 \mathrm{mmol}$; 1.5 eq.) was added in portions. After $2 \mathrm{~h}$ the reaction mixture was diluted with $\mathrm{CH}_{2} \mathrm{Cl}_{2}$, filtered and concentrated in vacuo. The crude was dried by azeotropic co-evaporation using toluene, whereafter it was dissolved in dry THF $(30 \mathrm{~mL})$ followed by the addition of $\mathrm{PhMgBr}$ (ca. $40 \mathrm{mmol}$ in THF) at $0{ }^{\circ} \mathrm{C}$. The reaction was quenched with $\mathrm{NH}_{4} \mathrm{Cl}$ (aq.) and extracted with ethyl acetate. The combined organic phases were washed with brine and concentrated in vacuo followed by purification using flash chromatography (ethyl acetatepetroleum ether $\left.1: 3 ; R_{\mathrm{f}}=0.3\right)$. A mixture of the two diastereomers of 16 was isolated (5.00 g; 88\%).

The mixture of alcohols $(\mathbf{1 6}, 2.00 \mathrm{~g} ; 7.13 \mathrm{mmol})$ was dissolved in pyridine (30 mL) and TsCl (4.08 g; $21.4 \mathrm{mmol} ; 3$ eq.) was added together with DMAP ( $87 \mathrm{mg} ; 0.1$ eq.). The reaction was stirred at $90{ }^{\circ} \mathrm{C}$ for $2.5 \mathrm{~h}$, additional $2 \mathrm{~g}$ of $\mathrm{TsCl}$ was added and stirring was continued for 2 days at room temperature. After concentration the crude residue was diluted with ethyl acetate. The ethyl acetate phase was washed with water, $\mathrm{HCl}$ ( $1 \mathrm{M}$ in water), $\mathrm{NaHCO}_{3}$ and finally brine. After concentration in vacuo the residue was purified by flash chromatography (petroleum ether-ethyl acetate $3: 1)$ to give tosylate $(1.36 \mathrm{~g}$, 44\%). [ ${ }^{1} \mathrm{H}$ NMR (500 MHz, $\mathrm{CDCl}_{3}$ ) $\delta$ 7.87-7.01 (m, 5H, Ph, $\left.\mathrm{Ph}^{\prime}\right)$, $6.01\left(\mathrm{~d}, J=3.9 \mathrm{~Hz}, 0.25 \mathrm{H}, \mathrm{H}^{\prime}\right), 5.99$ (d, $\left.J=3.8 \mathrm{~Hz}, 0.75 \mathrm{H}, \mathrm{H} 1\right)$, 5.09 (bd, $\left.J=5.8 \mathrm{~Hz}, 0.25 \mathrm{H}, \mathrm{H} 5^{\prime}\right), 5.03$ (d, $J=7.8 \mathrm{~Hz}, 0.75 \mathrm{H}, \mathrm{H} 5$ ), $4.56\left(2 \times \mathrm{d}, J=3.8 \mathrm{~Hz}, J^{\prime}=3.8 \mathrm{~Hz}, 1 \mathrm{H}, \mathrm{H} 2, \mathrm{H} 2^{\prime}\right), 4.29(\mathrm{dd}, J=$ 5.8, 3.3 Hz, $0.25 \mathrm{H}, \mathrm{H}^{\prime}$ ), 4.24 (dd, $J=7.8,3.2 \mathrm{~Hz}, 0.75 \mathrm{H}, \mathrm{H} 4$ ), $3.71\left(\mathrm{~d}, J=3.3 \mathrm{~Hz}, 0.25 \mathrm{H}, \mathrm{H}^{\prime}\right), 3.42\left(\mathrm{~s}, 0.75 \mathrm{H}, \mathrm{Me}^{\prime}\right), 3.31$ (d, $J=$ $3.2 \mathrm{~Hz}, 0.75 \mathrm{H}, \mathrm{H} 3), 3.29$ (s, 2.25H, Me), 1.48 (s, 2.25H, Me), 1.46 (s, 0.75H, Me'), 1.35-1.30 (m, 6H, Me, $\left.\mathrm{Me}^{\prime}\right) .{ }^{13} \mathrm{C}$ NMR $\left(126 \mathrm{MHz}, \mathrm{CDCl}_{3}\right) \delta 141.4,139.7,128.5,128.4,128.1,127.7$, 127.0, 126.0 (Ph, $\left.\mathrm{Ph}^{\prime}\right), 111.9\left(\mathrm{CMe}_{2}\right), 111.6\left(\mathrm{C}^{\prime} \mathrm{Me}_{2}\right), 105.2(\mathrm{C} 1)$, 105.2 (C1'), 85.2 (C3'), 84.7 (C4), 84.0 (C3), 82.3 (C4'), 81.6 (C2), 81.1 (C2'), 72.4 (C5, C5'), 57.6 (3-OMe'), 57.4 (3-OMe), 26.8 (Me), 26.7 ( $\left.\left.\mathrm{Me}^{\prime}\right), 26.3(\mathrm{Me}), 26.2\left(\mathrm{Me}^{\prime}\right).\right]$

1,2-O-Isopropylidene-3- $O$-methyl-5- $C$-phenyl-5- $O$-tosyl- $\alpha$-L-idopentofuranose $(0.76 \mathrm{~g} ; 1.74 \mathrm{mmol})$ was dissolved in DMF (10 mL) and $\mathrm{NaN}_{3}(0.454 \mathrm{~g}, 7 \mathrm{mmol}, 4 \mathrm{eq}$.) was added. The mixture was stirred at $70{ }^{\circ} \mathrm{C}$ for $24 \mathrm{~h}$. The reaction mixture was diluted with ethyl acetate and washed with water (4 times) and brine. After concentration in vacuo the residue was purified using flash chromatography (ethyl acetate-petroleum ether $1: 4)$ to give $17(0.43 \mathrm{~g}, 80 \%)$.

${ }^{1} \mathrm{H}$ NMR (500 MHz, $\left.\mathrm{CDCl}_{3}\right) \delta 7.42-7.30(\mathrm{~m}, 5 \mathrm{H}, \mathrm{Ar}), 5.85(\mathrm{~d}$, $J=3.7 \mathrm{~Hz}, 1 \mathrm{H}, \mathrm{H} 1), 4.77$ (d, $J=10.0 \mathrm{~Hz}, 1 \mathrm{H}, \mathrm{H} 5), 4.61$ (d, $J=$ $3.7 \mathrm{~Hz}, 1 \mathrm{H}, \mathrm{H} 2), 4.30$ (dd, $J=10.0,3.1 \mathrm{~Hz}, 1 \mathrm{H}, \mathrm{H} 4), 3.90$ (d, $J=$ $3.1 \mathrm{~Hz}, 1 \mathrm{H}, \mathrm{H} 3), 3.53$ (s, 3H, OMe), 1.46 (s, 3H, Me), 1.30 (s, 3H, Me).

${ }^{13} \mathrm{C}$ NMR (126 MHz, $\mathrm{CDCl}_{3}$ ) $\delta 137.1$ (Ar), 128.9 (Ar), 128.9 (Ar), 128.7 (Ar), 127.9 (Ar), $111.9\left(\mathrm{CMe}_{2}\right), 105.4$ (C1), 83.7 (C3), 81.8 (C4), 81.3 (C2), 63.1 (C5), 57.9 (OMe), 27.0 (Me), 26.4 (Me).

IR: $-\mathrm{N}_{3} 2104 \mathrm{~cm}^{-1}$.
HRMS calculated $\mathrm{C}_{15} \mathrm{H}_{19} \mathrm{~N}_{3} \mathrm{O}_{4}+\mathrm{Na}^{+}=328.1268$ found: 328.1288 .

\section{1,5-Dideoxy-1,5-imino-3-O-methyl-5-C-phenyl-D-gluco-pentitol}

(18)

Azide 17 (562 mg; $1.84 \mathrm{mmol}$ ) was dissolved in $\mathrm{AcOH}$ (75\% in water) and refluxed for $2 \mathrm{~h}$. TLC (ethyl acetate-petroleum ether $1: 4)$ showed full conversion of the starting material and the solvent was removed under vacuum. The residue was purified by chromatography (ethyl acetate : petroleum ether $1: 1$ ) to give 5-azido-5-deoxy-3-O-methyl-5-C-phenyl-D-gluco-pentofuranose (404 mg, $1.52 \mathrm{mmol}, 83 \%$ ). This compound was dissolved in $\mathrm{MeOH}(20 \mathrm{~mL})$ and $\mathrm{Pd} / \mathrm{C}(162 \mathrm{mg})$ was added. To the reaction mixture was then added $\mathrm{Et}_{3} \mathrm{SiH}$ (2.65 g; $22.8 \mathrm{mmol}, 15 \mathrm{eq}$.) in portions via syringe. $\mathrm{Pd} / \mathrm{C}$ was removed by filtration through Celite, which was then washed carefully with $\mathrm{MeOH}$. The filtrate was concentrated and purified by chromatography $\left(\mathrm{CH}_{2} \mathrm{Cl}_{2}-\mathrm{MeOH} 9: 1\right)$ to give 18 (144 mg, 42\%).

${ }^{1} \mathrm{H}$ NMR (500 MHz, DMSO-d 6 ) $\delta 7.49-7.35$ (m, 5H, Ar), 3.72 (ddd, $J=11.1,9.1,5.3 \mathrm{~Hz}, 1 \mathrm{H}, \mathrm{H} 5), 3.64(\mathrm{dd}, J=10.0,9.1 \mathrm{~Hz}$, 1H, H3), 3.62 (s, 3H, Me), 3.50 (d, $J=10.0 \mathrm{~Hz}, 1 \mathrm{H}, \mathrm{H} 2), 3.21$ (t, $J=9.1 \mathrm{~Hz}, 1 \mathrm{H}, \mathrm{H} 4), 3.14(\mathrm{dd}, J=12.1,5.3 \mathrm{~Hz}, 1 \mathrm{H}, \mathrm{H} 6), 2.61$ (dd, $J=12.1,11.1 \mathrm{~Hz}, 1 \mathrm{H}, \mathrm{H6}^{\prime}$ ).

${ }^{13} \mathrm{C}$ NMR (126 MHz, DMSO-d 6 ) $\delta 138.3$ (Ar), $127.9(\mathrm{Ar}), 127.3$ (Ar), 127.0 (Ar), 87.3 (C4), 73.3 (C3), 69.4 (C5), 64.2 (C2), 58.9 (Me), 48.7 (C6).

$[\alpha]_{\mathrm{D}} 40.5^{\circ}(c 1.0, \mathrm{MeOH})$.

HRMS calculated $\mathrm{C}_{12} \mathrm{H}_{18} \mathrm{NO}_{3}=224.1281$ found: 224.1264 .

\section{1,5-Dideoxy-1,5-imino-3-O-methyl-5- $C$-phenyl-L-ido-pentitol}

(20)

12 (1.323 g; $4.61 \mathrm{mmol}$ ) was dissolved in DMF (25 mL) cooled to $0{ }^{\circ} \mathrm{C}$, where $\mathrm{NaH}$ ( $221 \mathrm{mg} ; 60 \%$ dispersion; 2 eq.) was added followed by MeI (0.6 mL; $1.31 \mathrm{~g} ; 9.22 \mathrm{mmol} ; 2$. eq.). After $1 \mathrm{~h}$ the reaction was quenched with water and diluted with EA. The phases were separated and the organic phase was washed with water ( 5 times) followed by brine and drying over $\mathrm{MgSO}_{4}$. The crude 19 was concentrated on Celite and purified by flash chromatography (petroleum ether:ethyl acetate 1:1). Yield $1.28 \mathrm{~g}$ (91\%). [ ${ }^{1} \mathrm{H}$ NMR (500 MHz, $\left.\mathrm{CDCl}_{3}\right) \delta 7.46-7.29(\mathrm{~m}, 5 \mathrm{H})$, 5.99 (d, $J=3.8 \mathrm{~Hz}, 1 \mathrm{H}, \mathrm{H} 1), 4.82$ (d, $J=9.5 \mathrm{~Hz}, 1 \mathrm{H}, \mathrm{H} 5), 4.50$ (d, $J=3.8 \mathrm{~Hz}, 1 \mathrm{H}, \mathrm{H} 2$ ), 4.33 (dd, $J=9.5,3.1 \mathrm{~Hz}, 1 \mathrm{H}, \mathrm{H} 4), 3.16$ (s, 3H, OMe), 3.11 (d, J = 3.1 Hz, 1H, H3), 1.51 (s, 3H, Me), 1.31 (s, 3H, Me). ${ }^{13} \mathrm{C}$ NMR (126 MHz, $\mathrm{CDCl}_{3}$ ) $\delta 136.4(\mathrm{Ar}), 128.8(\mathrm{Ar})$, 128.8 (Ar), 127.8 (Ar), $112.0\left(\mathrm{CMe}_{2}\right), 105.6$ (C1), 83.8 (C3), 83.5 (C4), 81.2 (C2), 64.9 (C5), 57.4 (OMe), 26.9 (Me), 26.3 (Me).]

Azide 19 (1.279 g; $4.19 \mathrm{mmol})$ was dissolved in acetic acid (75\% in water; $75 \mathrm{~mL}$ ) and refluxed for $1.5 \mathrm{~h}$, where TLC (ethyl acetate-petroleum ether $4: 1$ ) showed full conversion of the starting material. The reaction mixture was concentrated in vacuo and the crude product was purified by chromatography (ethyl acetate: petroleum ether $1: 1$ ) to give 5-azido-5deoxy-3-O-methyl-5-C-phenyl-L-ido-pentofuranose (766 mg; $2.89 \mathrm{mmol} ; 69 \%)$. It was redissolved in $\mathrm{MeOH}(40 \mathrm{~mL})$ and $\mathrm{Pd} / \mathrm{C}(307 \mathrm{mg})$ was added under a nitrogen atmosphere. $\mathrm{Et}_{3} \mathrm{SiH}$ (6.91 mL; $5.0 \mathrm{~g} ; 15$ eq.) was added in portions via syringe, and 
the reaction was allowed to stir for $2 \mathrm{~h}$ where TLC (ethyl acetate : petroleum ether $1: 1$ and $\left.\mathrm{CH}_{2} \mathrm{Cl}_{2}: \mathrm{MeOH} 9: 1\right)$ showed full conversion. The reaction mixture was filtered through Celite, which was then washed carefully with $\mathrm{MeOH}$. The filtrate was concentrated in vacuo and purified by chromatography $\left(\mathrm{CH}_{2} \mathrm{Cl}_{2}: \mathrm{MeOH} 9: 1\right)$. Yield $243 \mathrm{mg}$ (38\%).

${ }^{1} \mathrm{H}$ NMR $\left(500 \mathrm{MHz}, \mathrm{D}_{2} \mathrm{O}\right) \delta 7.70-7.39(\mathrm{~m}, 5 \mathrm{H}, \mathrm{Ar}), 4.62$ (bs, 1H, H2), 4.30 (bs, 1H, H5), 4.25 (d, J<3 Hz, 1H, H3), 3.79 (dd, $J<3 \mathrm{~Hz}, 1 \mathrm{H}, \mathrm{H} 4), 3.60$ (bd, $J=13.7 \mathrm{~Hz}, 1 \mathrm{H}, \mathrm{H} 6), 3.53$ (s, 3H, $\mathrm{Me}$ ), 3.53 (bd, $J=13.7 \mathrm{~Hz}, 1 \mathrm{H}, \mathrm{H6}^{\prime}$ ).

${ }^{13} \mathrm{C}$ NMR (126 MHz, $\left.\mathrm{D}_{2} \mathrm{O}\right) \delta 133.6(\mathrm{Ar}), 129.1$ (Ar), 129.1 (Ar), 126.9 (Ar), 76.4 (C4), 68.4 (C3), 63.2 (C5), 58.7 (C2), 57.8 (Me), 46.9 (C6).

$[\alpha]_{\mathrm{D}} 56.8^{\circ}(c 1.0, \mathrm{MeOH})$.

HRMS calculated $\mathrm{C}_{12} \mathrm{H}_{18} \mathrm{NO}_{3}=224.1281$ found: 224.1301 .

\section{3-O-Benzyl-1,5-dideoxy-1,5-imino-5- $C$-phenyl-D-gluco-pentitol} (21)

Azide 14 (0.88 g; $2.31 \mathrm{mmol})$ was dissolved in $50 \mathrm{~mL}$ acetic acid (75\% in water) and refluxed for $1.5 \mathrm{~h}$, where TLC (PE-EA $4: 1)$ showed full conversion of the starting material. The reaction was concentrated in vacuo and purified by flash chromatography (ethyl acetate : petroleum ether $1: 1$ ) to give 5-azido-3-Obenzyl-5-deoxy-5- $C$-phenyl-D-gluco-pentofuranose $(0.61 \mathrm{mg}$; $77 \%)$. A portion of this material $(102 \mathrm{mg} ; 0.30 \mathrm{mmol})$ was dissolved in $5 \mathrm{~mL} \mathrm{MeOH}$ and $\mathrm{Pd} / \mathrm{C}(32 \mathrm{mg}$ ) was added under a nitrogen atmosphere followed by $\mathrm{Et}_{3} \mathrm{SiH}(0.9 \mathrm{~mL} ; 4.5 \mathrm{mmol}$; 15 eq.). The reaction was stirred for $3.5 \mathrm{~h}$ where TLC (ethyl acetate : petroleum ether $1: 1$ and $\mathrm{CH}_{2} \mathrm{Cl}_{2}-\mathrm{MeOH} 9: 1$ ) showed full conversion. The reaction mixture was filtered through Celite, which was then washed carefully with $\mathrm{MeOH}$. The filtrates were concentrated in vacuo and purified by flash chromatography $\left(\mathrm{CH}_{2} \mathrm{Cl}_{2}-\mathrm{MeOH} 9: 1\right)$ to give the product (69 mg; $77 \%)$.

${ }^{1} \mathrm{H}$ NMR (500 MHz, $\left.\mathrm{CDCl}_{3}\right) \delta 7.75-7.01(\mathrm{~m}, 10 \mathrm{H}, \mathrm{Ar}), 4.94$ (d, $J=11.5 \mathrm{~Hz}, 1 \mathrm{H}, \mathrm{Bn}), 4.81$ (d, $J=11.5 \mathrm{~Hz}, 1 \mathrm{H}, \mathrm{Bn}), 3.74$ (ddd, $J=9.7,9.1,5.3 \mathrm{~Hz}, 1 \mathrm{H}, \mathrm{H} 5), 3.57$ (t, $J=9.1 \mathrm{~Hz}, 1 \mathrm{H}, \mathrm{H} 3$ ), $3.44(\mathrm{~d}, J=9.1 \mathrm{~Hz}, 1 \mathrm{H}, \mathrm{H} 2), 3.32$ (t, $J=9.1 \mathrm{~Hz}, 1 \mathrm{H}, \mathrm{H} 4), 3.20$ (dd, $J=11.3,5.3 \mathrm{~Hz}, 1 \mathrm{H}), 2.62\left(\mathrm{dd}, J=11.3,9.7 \mathrm{~Hz}, 1 \mathrm{H}, \mathrm{H6}^{\prime}\right)$.

${ }^{13} \mathrm{C} \mathrm{NMR}\left(126 \mathrm{MHz}, \mathrm{CDCl}_{3}\right.$ ) $\delta 140.0$ (Ar), 138.9 (Ar), 128.8 (Ar), 128.7 (Ar), 128.7 (Ar), 128.3 (Ar), 128.1 (Ar), 128.0 (Ar), 128.0 (Ar), 87.6 (C4), 76.3 (Bn), 75.1 (C3), 71.2 (C5), 66.6 (C2), 50.7 (C6).

HRMS calculated for $\mathrm{C}_{18} \mathrm{H}_{22} \mathrm{NO}_{3}=300.1594$ found: 300.1592 .

\section{3-O-Benzyl- $\mathrm{N}$-tert-butoxycarbonyl-1,5-dideoxy-1,5-imino-2,4-di- $O$-methyl-5-C-phenyl-D-gluco-pentitol (22)}

Diol 21 (300 mg; $1.0 \mathrm{mmol}$ ) was dissolved in THF : water (1: 1; $10 \mathrm{~mL})$, cooled to $0{ }^{\circ} \mathrm{C}$ in an ice bath. $\mathrm{NaHCO}_{3}(152 \mathrm{mg}$; 1.1 eq.; $1.1 \mathrm{mmol}$ ) was added followed by Boc-anhydride (327 mg; 1.50 mmol, 1.5 eq.) and additional 1.1 eq. of $\mathrm{NaHCO}_{3}$ in $6 \mathrm{~mL}$ THF : water $(1: 1)$. The reaction was allowed to reach room temperature, where it was kept stirred for $24 \mathrm{~h}$. TLC $\left(\mathrm{CH}_{2} \mathrm{Cl}_{2}-\mathrm{MeOH} 9: 1\right)$ indicated full conversion, and the reaction mixture was concentrated to remove THF and then diluted with ethyl acetate. The organic phase was washed with water three times, brine, dried over $\mathrm{MgSO}_{4}$ and concentrated in vacuo. Flash chromatography $\left(\mathrm{CH}_{2} \mathrm{Cl}_{2}-\mathrm{MeOH} 19: 1\right)$ yielded the Boc protected piperidine (289 $\mathrm{mg}, 72 \%$ ). Most of this compound (280 $\mathrm{mg} ; 0.70 \mathrm{mmol}$ ) was dissolved in dry DMSO (30 mL) and added to degreased $\mathrm{NaH}$ (7.4 mmol; 10 eq.) followed by MeI (450 $\mu \mathrm{l} ; 7.4 \mathrm{mmol} ; 10$ eq.). The reaction was stirred for $2 \mathrm{~h}$, where TLC (ethyl acetate-petroleum ether 1:1) indicated full conversion of the starting material. The reaction was quenched with water and the aqueous phase was extracted with $\mathrm{CH}_{2} \mathrm{Cl}_{2}(3 \times 60 \mathrm{~mL})$. The combined organic phases were washed with water (2 times), brine and dried $\left(\mathrm{MgSO}_{4}\right)$ followed by concentration in vacuo to give the title product $(250 \mathrm{mg}$; $83 \%)$.

${ }^{1} \mathrm{H}$ NMR (500 MHz, $\left.\mathrm{CDCl}_{3}\right) \delta 7.43-6.94(\mathrm{~m}, 10 \mathrm{H}, \mathrm{Ar}), 4.62$ (m, 3H, Bn, H2), 4.17 (dd, $J=14.4,3.1 \mathrm{~Hz}, 1 \mathrm{H}, \mathrm{H} 6$ ), 3.53 (dd, $J=7.8,3.7 \mathrm{~Hz}, 1 \mathrm{H}, \mathrm{H} 4), 3.46(\mathrm{ddd}, J=3.7,3.2,3.1 \mathrm{~Hz}, 1 \mathrm{H}, \mathrm{H} 5)$, $3.41(\mathrm{t}, J=7.8 \mathrm{~Hz}, 1 \mathrm{H}), 3.32(\mathrm{~s}, 3 \mathrm{H}, \mathrm{OMe}), 3.31(\mathrm{~d}, J=14.4,3.2$ $\mathrm{Hz}, 0 \mathrm{H}), 3.16$ (s, 3H, OMe), 1.18 (s, 9H, $\mathrm{CMe}_{3}$ ).

${ }^{13} \mathrm{C}$ NMR $\left(126 \mathrm{MHz}, \mathrm{CDCl}_{3}\right) \delta 155.5(\mathrm{C}=\mathrm{O}), 142.0(\mathrm{Ar}), 138.5$ (Ar), 128.4 (Ar), 128.3 (Ar), 128.3 (Ar), 127.6 (Ar), $127.0(\mathrm{Ar})$, 126.5 (Ar), 83.6 (C4), 83.4 (C3), 81.4 (C5), $80.1\left(\mathrm{CMe}_{3}\right), 72.9$ (Bn), 60.1 (OMe), 59.6 (C2), 56.6 (OMe), 40.8 (C6), $28.3\left(\mathrm{CMe}_{3}\right)$.

HRMS calculated for $\mathrm{C}_{25} \mathrm{H}_{33} \mathrm{NO}_{5} \mathrm{Na}=450.2256$ found: 450.2247 .

\section{1,5-Dideoxy-1,5-imino-2,4-di-O-methyl-5-C-phenyl-D-gluco- pentitol (23)}

Compound 22 (235 mg; $0.55 \mathrm{mmol}$ ) was dissolved in $10 \mathrm{~mL}$ $\mathrm{MeOH}$ : acetic acid $(1: 1)$ and the solution was saturated with hydrogen gas using a balloon equipped with a long needle. The atmosphere in the flask was when exchanged with nitrogen and $\mathrm{Pd}(\mathrm{OH})_{2}(50 \mathrm{mg})$ was added followed by flushing with hydrogen gas. After $24 \mathrm{~h}$ under a hydrogen atmosphere TLC showed that the reaction was incomplete and an additional $50 \mathrm{mg} \mathrm{Pd}(\mathrm{OH})_{2}$ was added. This was repeated after additional $24 \mathrm{~h}$, whereafter the reaction was left for further $72 \mathrm{~h}$ with $50 \mathrm{mg}$ fresh catalyst. The crude reaction mixture was filtered through Celite, which was then washed carefully with $\mathrm{MeOH}$. The filtrate was concentrated in vacuo and purified by flash chromatography (petroleum ether: ethyl acetate 1:1+1\% $\mathrm{Et}_{3} \mathrm{~N}$ ) to give the debenzylated product (130 mg; 70\%). Some of this product ( $57 \mathrm{mg} ; 0.15 \mathrm{mmol})$ was treated with TFA $(400 \mu \mathrm{l})$ in $\mathrm{CH}_{2} \mathrm{Cl}_{2}(4 \mathrm{~mL})$. After $18 \mathrm{~h}$ TLC (ethyl acetate-petroleum ether $4: 1+1 \% \mathrm{Et}_{3} \mathrm{~N}$ ) showed full conversion, and the reaction was filtered and concentrated in vacuo to give the title product. Yield: $60 \mathrm{mg}$ (quantitative).

${ }^{1} \mathrm{H}$ NMR (500 MHz, $\left.\mathrm{CDCl}_{3}\right) \delta 7.59-7.40(\mathrm{~m}, 5 \mathrm{H}, \mathrm{Ar}), 4.27$ (d, $J=10.3 \mathrm{~Hz}, 1 \mathrm{H}, \mathrm{H} 5) ; 3.83(\mathrm{dd}, J=9.2,10.3 \mathrm{~Hz}, 1 \mathrm{H}, \mathrm{H} 4), 3.82$ (dd, $J=12.5,5.2 \mathrm{~Hz}, 1 \mathrm{H}, \mathrm{H} 1 \mathrm{a}) ; 3.79$ (dd, $J=9.2,9.2 \mathrm{~Hz}, 1 \mathrm{H}$, H3), 3.73 (ddd, $J=11.2,9.2,5.2 \mathrm{~Hz}, 1 \mathrm{H}, \mathrm{H} 2$ ), 3.56 (s, $3 \mathrm{H}, \mathrm{Me}$ ), 3.12 (s, 3H, Me), 3.08 (dd, $J=12.5,11.2 \mathrm{~Hz}$ ).

${ }^{13} \mathrm{C}$ NMR (126 MHz, D $2 \mathrm{O}$, DMSO log tube) $\delta 131.0$ (Ar), 129.4 (Ar), 128.7 (Ar), 127.3 (Ar), 80.0 (C3), 75.5 (C2), 74.0 (C4), 60.9 (C5), 59.2 (Me), 57.6 (Me), 43.0 (C1).

$[\alpha]_{\mathrm{D}} 33.4^{\circ}(c 1.0, \mathrm{MeOH})$. 
HRMS calculated for $\mathrm{C}_{13} \mathrm{H}_{20} \mathrm{NO}_{3}=238.1438$ found: 238.1437.

5-Azido-3-O-benzyl-5-deoxy-1,2-O-isopropylidene-5- $C$-phenyl$\alpha$-L-ido-pentofuranose (24)

Compound 12 (105 mg; $0.36 \mathrm{mmol}$ ) was dissolved in dry DMF $(2.5 \mathrm{~mL})$ and cooled to $0{ }^{\circ} \mathrm{C}$ in an ice bath, and $\mathrm{NaH}(60 \%$ dispersion) (19 mg; $0.79 \mathrm{mmol} ; 2.2$ eq.) was added. $\mathrm{BnCl}(0.5 \mathrm{~mL})$ was added under an atmosphere of nitrogen, and the reaction was stirred for $1 \mathrm{~h}$ at $0{ }^{\circ} \mathrm{C}$ followed by $1.5 \mathrm{~h}$ at room temperature, where TLC (petroleum ether: ethyl acetate $3: 1$ ) showed full conversion. The reaction was quenched with water and diluted with ethyl acetate. The phases were separated, and the organic phase was washed with water (3 times), brine and dried over $\mathrm{MgSO}_{4}$, filtered and concentrated in vacuo. The crude residue was purified by flash chromatography (petroleum ether-ethyl acetate $6: 1$ ) to give the product $(128 \mathrm{mg}$; $93 \%)$.

${ }^{1} \mathrm{H}$ NMR (500 MHz, chloroform-d) $\delta 7.41-7.22$ (m, 10H, Ar), 6.04 (d, $J=3.8 \mathrm{~Hz}, 1 \mathrm{H}, \mathrm{H} 1), 4.88$ (d, $J=9.6 \mathrm{~Hz}, 1 \mathrm{H}, \mathrm{H} 5), 4.57$ (d, $J=3.8 \mathrm{~Hz}, 1 \mathrm{H}, \mathrm{H} 2$ ), 4.49 (dd, $J=9.6,3.2 \mathrm{~Hz}, 1 \mathrm{H}, \mathrm{H} 4), 4.43$ (d, $J=11.3 \mathrm{~Hz}, 1 \mathrm{H}, \mathrm{Bn}), 4.09$ (d, $J=11.3 \mathrm{~Hz}, 1 \mathrm{H}, \mathrm{Bn}), 3.47$ (d, $J=3.2 \mathrm{~Hz}, 1 \mathrm{H}, \mathrm{H} 3$ ), 1.55 (s, 3H, Me), 1.32 (s, 3H, Me).

${ }^{13} \mathrm{C}$ NMR (126 MHz, $\mathrm{CDCl}_{3}$ ) $\delta 136.9(\mathrm{Ar}), 136.0$ (Ar), 128.7 $(2 \times \mathrm{C}, \mathrm{Ar}), 128.4$ (Ar), 127.9 (Ar), 127.7 (Ar), 127.6 (Ar), 111.8 $\left(\mathrm{CMe}_{2}\right), 105.3$ (C1), 83.4 (C3), 81.6 (C4), 81.5 (C2), 71.8 (Bn), 64.7 (C5), 26.8 (Me), 26.2 (Me).

HRMS calculated $\mathrm{C}_{21} \mathrm{H}_{23} \mathrm{~N}_{3} \mathrm{O}_{4}+\mathrm{Na}^{+}=404.1586$ found: 404.1556.

\section{3-O-Benzyl-1,5-dideoxy-1,5-imino-5-C-phenyl-D-gluco-pentitol}

(25)

Compound 24 (461 mg; $1.21 \mathrm{mmol}$ ) was dissolved in $60 \mathrm{~mL}$ $75 \%$ aqueous acetic acid and refluxed for $2 \mathrm{~h}$, where TLC (petroleum ether : ethyl acetate $4: 1$ ) showed full conversion. After concentration in vacuo the residue was purified by flash chromatography (petroleum ether: ethyl acetate $2: 1$ ) to give 5-azido-3-O-benzyl-5-deoxy-5-C-phenyl-L-ido-pentofuranose

(292 $\mathrm{mg} ; 71 \%$ ). This was then dissolved in $\mathrm{MeOH}(15 \mathrm{~mL})$ and $\mathrm{Pd} / \mathrm{C}(10 \% ; 90 \mathrm{mg})$ was added followed by $\mathrm{Et}_{3} \mathrm{SiH}(2 \mathrm{~mL}$; $12.8 \mathrm{mmol} ; 15$ eq.). After $2 \mathrm{~h}$ TLC (petroleum ether: ethyl acetate $1: 1$ and $\left.\mathrm{CH}_{2} \mathrm{Cl}_{2}: \mathrm{MeOH} 9: 1\right)$ showed full conversion and the reaction was filtered through Celite, which was then carefully washed with $\mathrm{MeOH}$. After concentration in vacuo the residue was purified by flash chromatography $\left(\mathrm{CH}_{2} \mathrm{Cl}_{2}-\mathrm{MeOH}\right.$ $14: 1)$ to give 25 (101 $\mathrm{mg}, 39 \%)$.

${ }^{1} \mathrm{H}$ NMR (500 MHz, $\left.\mathrm{CDCl}_{3}\right) \delta 7.43-7.19(\mathrm{~m}, 10 \mathrm{H}, \mathrm{Ar}), 4.61$ (d, $J=11.9 \mathrm{~Hz}, 1 \mathrm{H}, \mathrm{Bn}), 4.57$ (d, $J=11.9 \mathrm{~Hz}, 1 \mathrm{H}, \mathrm{Bn}), 4.02$ (bs, 1H, H2), 3.78 (bs, 2H, H4, H5), 3.74 (bs, 1H, H3), 3.09 (m, 2H, H6, $\left.\mathrm{H6}^{\prime}\right)$.

${ }^{13} \mathrm{C}$ NMR (126 MHz, $\mathrm{CDCl}_{3}$ ) $\delta 139.9(\mathrm{Ar}), 138.2(\mathrm{Ar}), 128.7$ (Ar), 128.6 (Ar), 128.0 (Ar), 127.7 (Ar), 127.7 (Ar), $127.2(\mathrm{Ar})$, 76.0 (C4), 72.3 (Bn), 70.9 (C3), 66.2 (C5), 59.0 (C2), 48.3 (C6).

HRMS calculated $\mathrm{C}_{18} \mathrm{H}_{22} \mathrm{NO}_{3}=300.1594$ found: 300.1597 .
3-O-Benzyl- $N$-tert-butoxycarbonyl-1,5-dideoxy-1,5-imino-2,4-di$O$-methyl-5-C-phenyl-t-ido-pentitol (26)

Compound 25 (101 mg; $0.34 \mathrm{mmol}$ ) was dissolved in $3 \mathrm{~mL}$ THF-water $(1: 1)$ and cooled to $0{ }^{\circ} \mathrm{C}$ in an ice bath. $\mathrm{Na}_{2} \mathrm{CO}_{3}$ (40 mg, $0.37 \mathrm{mmol}, 1.1 \mathrm{eq}$.) was added to the solution followed by Boc anhydride (110 mg, $0.50 \mathrm{mmol}, 1.5 \mathrm{eq}$.$) together with$ additional $40 \mathrm{mg} \mathrm{Na}_{2} \mathrm{CO}_{3}$ dissolved in $2 \mathrm{~mL}$ THF-water $(1: 1)$. The reaction mixture was left at $0{ }^{\circ} \mathrm{C}$ for $30 \mathrm{~min}$ and thereafter at room temperature for $23 \mathrm{~h}$ where $\mathrm{TLC}\left(\mathrm{CH}_{2} \mathrm{Cl}_{2}-\mathrm{MeOH} 9: 1\right)$ showed full conversion. THF and water were partly removed by evaporation and the rest were diluted with ethyl acetate followed by washing the organic phase with water (3 times) and brine before drying it $\left(\mathrm{MgSO}_{4}\right)$. Concentration in vacuo and subsequent purification by flash chromatography $\left(\mathrm{CH}_{2} \mathrm{Cl}_{2}-\right.$ $\mathrm{MeOH} 29: 1$ ) gave the Boc derivative (104 mg; $0.26 \mathrm{mmol}$; $77 \%)$. This intermediate was redissolved in dry DMSO $(10 \mathrm{~mL})$ and added to a flask containing degreased $\mathrm{NaH}(110 \mathrm{mg}$ as $60 \%$ dispersion; 10 eq.) together with $\mathrm{MeI}(170 \mu \mathrm{l} ; 2.72 \mathrm{mmol}$; 10 eq.). The reaction was stirred for $1.5 \mathrm{~h}$ where TLC (ethyl acetate-petroleum ether $1: 1$ ) showed full conversion and was then quenched with water. The reaction mixture was extracted with $\mathrm{CH}_{2} \mathrm{Cl}_{2}$, and the combined organic phases were washed with water (2 times) and brine followed by drying over $\mathrm{MgSO}_{4}$ and concentration in vacuo to give the title product 26 (99 mg; $89 \%)$.

${ }^{1} \mathrm{H}$ NMR (500 MHz, $\left.\mathrm{CDCl}_{3}\right) \delta 7.54-7.39(\mathrm{~m}, 2 \mathrm{H}), 7.37-7.11$ $(\mathrm{m}, 8 \mathrm{H}), 5.70(\mathrm{~s}, 0.5 \mathrm{H}), 5.38(\mathrm{~s}, 0.5 \mathrm{H}), 4.86-4.70(\mathrm{~m}, 2 \mathrm{H}), 4.22$ $(\mathrm{s}, 0.5 \mathrm{H}), 3.94(\mathrm{~s}, 0.5 \mathrm{H}), 3.76(\mathrm{~s}, 1 \mathrm{H}), 3.54-3.44(\mathrm{~m}, 1 \mathrm{H})$, 3.45-3.13 (m, 7H), 2.47 (m, 1H), 1.38 (m, 9H).

${ }^{13} \mathrm{C}$ NMR $\left(126 \mathrm{MHz}, \mathrm{CDCl}_{3}\right) \delta 155.0(\mathrm{C}=\mathrm{O}), 139.0,138.1$ (broad), 137.4 (broad), 128.6 (broad), 128.4, 128.4, 128.1 (broad), 128.0, 127.6, 127.2, 83.0 (broad), 82.1 (broad), 81.3 (broad), 80.7 (broad), $80.6\left(\mathrm{CMe}_{3}\right), 80.3$ (broad), 75.3 (broad), 74.7 (broad), 58.8 (broad), 58.5 (broad), 55.3 (broad), 53.7 (broad), 41.8 (broad), 41.0 (broad), $28.4\left(\mathrm{CMe}_{3}\right)$.

$[\alpha]_{\mathrm{D}} 27.0^{\circ}\left(c 1.0, \mathrm{CHCl}_{3}\right)$.

HRMS calculated for $\mathrm{C}_{25} \mathrm{H}_{33} \mathrm{NO}_{5} \mathrm{Na}=450.2251$ found: 450.2249 .

\section{1,5-Dideoxy-1,5-imino-2,4-di- $O$-methyl-5- $C$-phenyl-L-ido- pentitol (27)}

26 (84 mg; $0.20 \mathrm{mmol}$ ) was dissolved in $\mathrm{MeOH}: \mathrm{AcOH}$ (1: 1; $3 \mathrm{~mL}$ ) and the solution was saturated with hydrogen gas before $50 \mathrm{mg} \mathrm{Pd}(\mathrm{OH})_{2}$ was added under an atmosphere of nitrogen. The reaction was left for $20 \mathrm{~h}$ under a hydrogen atmosphere. TLC (petroleum ether-ethyl acetate 1:1+1\% $\mathrm{Et}_{3} \mathrm{~N}$ ) showed full conversion, and the reaction was filtered through Celite, which was then washed carefully with $\mathrm{MeOH}$. The solution was concentrated in vacuo to give the debenzylated product (50 mg; 76\%). [ ${ }^{1} \mathrm{H}$ NMR (500 MHz, $\left.\mathrm{CDCl}_{3}\right) \delta 7.46-7.34(\mathrm{~m}, 5 \mathrm{H}$, $\mathrm{Ar}$, 4.22 (bs, 1H, H2), 4.22 (bm, 1H, H4), 3.46 (bm, 1H, H3), $3.44(\mathrm{~s}, 3 \mathrm{H}, \mathrm{Me}), 3.33(\mathrm{bm}, J=3.6 \mathrm{~Hz}, 1 \mathrm{H}, \mathrm{H} 5), 3.10(\mathrm{~s}, 3 \mathrm{H}$, $\mathrm{Me}$ ), 3.09-3.04 (bm, $\left.J=14.4,3.6 \mathrm{~Hz}, 2 \mathrm{H}, \mathrm{H} 6, \mathrm{H} 6{ }^{\prime}\right) .{ }^{13} \mathrm{C} \mathrm{NMR}$ (126 MHz, DMSO-d 6 ) $\delta$ 138.6 (Ar), 127.5 (Ar), 126.3 (Ar), 126.1 
(Ar), 80.5 (C3), 76.5 (C4), 65.5 (C5), 57.5 (Me), 55.7 (C2), 55.6 (Me), 41.7 (C6), $\left.[\alpha]_{\mathrm{D}} 39.9^{\circ}\left(c 1.0, \mathrm{CHCl}_{3}\right).\right]$

The Boc-protected intermediate $(50 \mathrm{mg} ; 0.15 \mathrm{mmol})$ was treated with TFA $(400 \mu \mathrm{l})$ in $\mathrm{CH}_{2} \mathrm{Cl}_{2}$ (4 ml containing $1 \%$ water) and concentrated to give the title product 27 (60 mg, quantitative).

${ }^{1} \mathrm{H}$ NMR (500 MHz, D $\left.2 \mathrm{O}\right) \delta$ 7.61-7.52 (m, 5H, Ar), $4.76(\mathrm{~d}$, $J=1.9 \mathrm{~Hz}, 0 \mathrm{H}), 4.43(\mathrm{dd}, J=3.1,1.4 \mathrm{~Hz}, 1 \mathrm{H}), 3.83-3.74(\mathrm{~m}$, $3 \mathrm{H}), 3.62(\mathrm{~d}, J=2.3 \mathrm{~Hz}, 1 \mathrm{H}), 3.60-3.57(\mathrm{~m}, 0 \mathrm{H}), 3.54(\mathrm{~d}, J=$ $1.9 \mathrm{~Hz}, 3 \mathrm{H}), 3.18$ (d, $J=1.9 \mathrm{~Hz}, 3 \mathrm{H})$.

${ }^{13} \mathrm{C}$ NMR (126 MHz, $\left.\mathrm{D}_{2} \mathrm{O}\right) \delta 163.1,162.8(\mathrm{C}=\mathrm{O}, \mathrm{TFA}), 138.3$ (Ar), 128.6 (Ar), 127.6 (Ar), 127.1 (Ar), 116.4 (q, $J=292 \mathrm{~Hz}, 1 \mathrm{C}$, TFA), 80.9, 76.8, 65.9, 58.7 (Me), 56.9 (C1), 56.8 (Me), 42.6 (C6).

$[\alpha]_{\mathrm{D}} 23.8^{\circ}(c 1.0, \mathrm{MeOH})$.

HRMS calculated for $\mathrm{C}_{13} \mathrm{H}_{20} \mathrm{NO}_{3}=238.1438$ found: 238.1439.

\section{Acknowledgements}

We acknowledge the Danish National Research Council (FNU) and the University of Copenhagen for support.

\section{Notes and references}

1 (a) L. P. Hammett, Chem. Rev., 1935, 17, 125; (b) R. W. Taft, J. Am. Chem. Soc., 1957, 79, 1045; (c) R. W. Taft and R. D. Topsom, Prog. Phys. Org. Chem., 1987, 16, 1.

2 (a) J. Clark and D. D. Perrin, Q. Rev., Chem. Soc., 1964, 18, 295; (b) S. Inouye, Chem. Pharm. Bull., 1968, 16, 1134.

3 (a) H. H. Jensen, L. Lyngbye, A. Jensen and M. Bols, Chem. - Eur. J., 2002, 8, 1218; (b) H. H. Jensen, L. Lyngbye and M. Bols, Angew. Chem., Int. Ed., 2001, 40, 3447.

4 (a) H. H. Jensen and M. Bols, J. Chem. Soc., Perkin Trans 1, 2001, 905; (b) H. H. Jensen, A. Jensen, R. Hazell and M. Bols, J. Chem. Soc., Perkin Trans. 1, 2002, 1190.

5 (a) A. V. Samoshin, I. S. Veselov, L. Huynh, A. K. Shestakova, V. A. Chertkov, G. V. Grishina and V. V. Samoshin, Tetrahedron Lett., 2011, 52, 5375; (b) A. V. Samoshin, H. Joo, A. Y. Korneichuk, I. S. Veselov, G. V. Grishina and V. V. Samoshin, Tetrahedron Lett., 2013, 54, 1020; (c) A. V. Samoshin, I. S. Veselov, V. A. Chertkov, A. A. Yaroslavov, G. V. Grishina, N. M. Samoshina and V. V. Samoshin, Tetrahedron Lett., 2013, 54, 5600; (d) V. V. Samoshin, B. Brazdova, V. A. Chertkov, D. E. Gremyachinskiy, A. K. Shestakova, E. K. Dobretsova, L. P. Vatlina, J. Yuan and H. J. Schneider, ARKIVOC, 2005, 129; (e) B. Brazdova, N. R. Zhang, V. V. Samoshin and X. Guo, Chem. Commun., 2008, 4774; $(f)$ Y. Terui and K. Tori, J. Chem. Soc., Perkin Trans. 2, 1975, 127; $(g)$ E. D. Goddard-Borger, M. B. Tropak, S. Yonekawa,
C. Tysoe, D. J. Mahuran and S. G. Withers, J. Am. Chem. Soc., 2012, 55, 2737.

6 J. O. Olsen, S. P. A. Sauer, C. M. Pedersen and M. Bols, Org. Biomol. Chem., 2015, 13, 3116.

7 L. Svansson, B. D. Johnston, J.-H. Gu, B. Patrick and B. M. Pinto, J. Am. Chem. Soc., 2000, 122, 1270.

8 (a) D. C. Lankin, N. S. Chandrakumar, S. N. Rao, D. P. Spangler and J. P. Snyder, J. Am. Chem. Soc., 1993, 115, 3356; (b) J. P. Snyder, N. S. Chandrakumar, H. Sato and D. C. Lankin, J. Am. Chem. Soc., 2000, 122, 544.

9 The piperidinium ion is still destabilized by the electronegative substituent, but the axial configuration is relatively more stabilized compared to the equatorial counterpart.

10 B. Bernet, U. Piantini and A. Vasella, Carbohydr. Res., 1990, 204, 11.

11 (a) H. H. Jensen and M. Bols, Acc. Chem. Res., 2006, 39, 259; (b) M. Heuckendorff, C. M. Pedersen and M. Bols, Chem. - Eur. J., 2010, 16, 13982.

12 (a) M. Bols, X. Liang and H. H. Jensen, J. Org. Chem., 2002, 67, 8970; (b) M. N. Namchuk, J. D. McCarter, A. Becalski, T. Andrews and S. G. Withers, J. Am. Chem. Soc., 2000, 122, 1270.

13 In the carbohydrate studies it has been found that methyl 3,6-anhydroglucoside hydrolyzes 446 times faster than the corresponding methyl $\alpha$-D-glucoside, more than the expected 100 times as estimated on the basis of $\sigma_{\mathrm{s}}$ values, which is probably due to the fact that besides being all axial the compound has one oxygen less. See: C. McDonnell, O. L. Lopez, P. Murphy, J. F. Bolanos, R. Hazell and M. Bols, J. Am. Chem. Soc., 2004, 126, 12374.

14 (a) C. M. Pedersen, L. U. Nordstrøm and M. Bols, J. Am. Chem. Soc., 2007, 129, 9222; (b) M. Heuckendorff, C. M. Pedersen and M. Bols, J. Org. Chem., 2012, 77, 5559.

15 H. H. Jensen, L. U. Nordstrøm and M. Bols, J. Am. Chem. Soc., 2004, 126, 9205.

16 R. U. Lemieux and J. Howard, Can. J. Chem., 1963, 41, 308316.

17 K. R. C. Prakash and S. P. Rao, Tetrahedron, 1993, 49, 15051510.

18 C. A. Grob and M. G. Schlageter, Helv. Chim. Acta, 1976, 59, 264.

19 The difference of 1.3 is also perfectly in accordance with the difference in base strength between benzylamine $\left(\mathrm{p} K_{\mathrm{a}}\right.$ 9.34) and methylamine ( $\mathrm{p} K_{\mathrm{a}}$ 10.66).

20 (a) F. Carey and R. J. Sundberg, Advanced Organic Chemistry, Kluever Academic Publishers, New York, 4th edn, 2002; (b) E. L. Eliel and M. C. Knoeber, J. Am. Chem. Soc., 1968, 90, 3444.

21 (a) H. S. Aaron, G. E. Wicks Jr. and C. P. Rader, J. Org. Chem., 1964, 29, 2248; (b) H. O. House, H. C. Miller, C. G. Pitt and P. P. Wickham, J. Org. Chem., 1963, 28, 2407. 